\title{
THE EFFECT OF ONLINE TRANSPORTATION SYSTEM ON UNEMPLOYMENT RATE AND PUBLIC WELFARE \\ IN INDONESIA
}

\author{
Darwis Harahap ${ }^{1}$, Ferri Alfadri ${ }^{2}$, Yenni Samri Juliati Nasution ${ }^{3}$, Nasir Ahmad Khan \\ Saragih $^{4}$ \\ darwisharahap@iain-padangsidimpuan.ac.id ${ }^{1}$, feri@iain-padangsidimpuan.ac.id ${ }^{2}$, \\ Yenni.samri@uinsu.ac.id ${ }^{3}$, dogecabitasaragih@gmail.com ${ }^{4}$
}

\begin{abstract}
The aim of this study was to examine the effect of online transportation system on the unemployment and public welfare in Medan City, Indonesia. Technology-based business practices in the industrial era 4.0 require certain skills in the area of works. Furthermore, changes to the technology system which initially absorbed more workers tend to decrease due to it replace human role. Consequently, the level of public welfare will also decline. This study was carried out at PT. GO-JEK Indonesia using the Structural Equation Modeling (SEM) method. The model used was a loading factor constructed from each indicator. The results of this study showed that an online transportation has effect on the reduction of the unemployment rate. Furthermore, it showed that this system may improve the welfare of the public. Therefore, online transportation has a positive effect on reducing unemployment and improving public welfare.
\end{abstract}

Keywords : Online Transportation, Unemployment, Public Welfare, PT. GO-JEK 


\section{Introduction}

According to World Economic Forum and The Future of Jobs Report since 2015 to 2020, there are 5 human resources capabilities in the industrial era 4.0. these include complex problem solving, social skills, process skills, system skills and cognitive abilities. Furthermore, at the end of 2020, it is estimated that the most needed skill will be cognitive abilities, followed by system skills, complex problem solving, content skills and process skills. These are needed to be prepared for the industrial era 4.0. It was seen that there has been a change in the position of cognitive abilities skills with regards to acquisition in this era. This is, because it increased from the last to the first position in 2020 and therefore, it had become an attraction and also a problem for individuals (Tansel and Ozdemir, 2018).

However, the industrial era 4.0 encourages humans to live in two worlds, namely the real and virtual world, as it relates to the existence of a system which forces individuals to acquire personal abilities. In addition, communication is highly dependent on the virtual world which continues to increase both in the complicated and smart stages. Consequently, this will have a negative impact on the work system because the change minimizes the use of labour due to replaces human role (Farrugia, 2019).

Furthermore, there was a significant difference between the increase in workforce and employment opportunities according to the level of education. It proves that an increase in educational level leads to a potential rise in the unemployment (Gao and Chen, 2019).

As one of the responses in recent years from the utilization of the 4.0 era, various options have emerged for both the educated and un-educated which enables them to work andto earn. One of the options was by utilizing technology assistance on existing gadgets/smartphones, i.e. the online transportation system. However, there was still unemployment registering to the company with this system including those who were already working (Martati, and Syarifuddin, 2013). Therefore, this has triggered an increase in the number of drivers with the online transportationsytem. In additional, there were various underlying reasons to why the consumers preferred this application. Therefore, online transportation system is considered cheaper and faster by $84.1 \%$ and $81.9 \%$ respectively (Okezone.com, 2018) 
Darwis Harahap, Ferri Alfadri, Yenni Samri Juliati Nasution, Nasir Ahmad Khan

The Effect of Online Transportation System on Unemployment Rate and Public Welfare in Indonesia

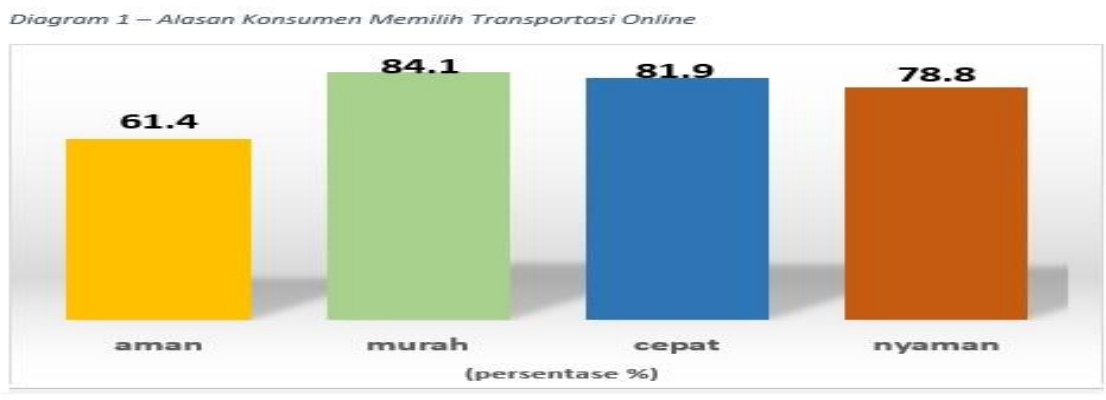

Figure 1. Consumers using online transportation system application

From the figure above, the reason for majority of the consumers was the price factor. The community considers the online transportation system cheaper and faster compared to others (Franita, 2016). The futhermore, as the use of this application increases, effective job opportunities will be created in the form of online transportation drivers. Therefore, the number of individuals working as drivers will continue to increase such as in PT. GO-JEK and Grab Indonesia.

In line with the branch opening rate of PT.GO-JEK in 50 cities, the unemployment rate has also been quite volatile (Sutia, Adha and Fahlevi, 2019). Based on the factors, it was analyzed that unemployment is one of the major aspects influencing the welfare level of Indonesians. This was respectively reviewed from Economic Aspect: This has an effectiveness because poverty increases when individuals do not have a source of income to meet their daily needs; Political aspect: The increasing rate of unemployment and difficulty in securing jobs cause violet demonstrations, which leads to an unstable political world; Mental aspects: The increase on the unemployment decreases the level of self-confidence which leads to depression; Social aspects: With high levels of unemployment, the rate of poverty, number of beggars, homeless people and buskers around the communityincrease; Security aspect: the increasing rate of unemployment leads the unemployed into committing crimes to support the economy in the house hold (riska, 2018).

Therefore, the public welfare in a country is measured by the level of effectiveness of the workforce.

Some definitions of online transportation proposed by experts are as follow: (Razak MASHUR et al., 2019). According to Ellen, online transportation system is a form of utilizing technological developments to support the development of work areas and national economy. (Altuzarra, Gálvez-Gálvez and González-Flores, 2019). According to Doni, an online transportation system is a form of transportation which operates by utilizing the development of knowledge on the technology. 
Along with the development of time, the number of drivers increases in every region. In addition, individuals choose to focus on being drivers and making it as the main source of income because of feeling comfortable while working for reasons, such as flexible working hours, greater income, hobby, part-time, love to meet new peopleand experiences from new places (Okerone.com, 2018)

Manpower productivity is required for the calculation of how much income must be received by the top worker sacrifice he has made. increased productivity can have a direct effect on the standard of living in improving the welfare of a worker (Özge KILIÇ, 2018).

Human resources contain two definitions. First, human resources contain the definition of work effort given in the production process. In this case human resources reflects the quality of effort that someone puts in a certain time to produce goods or services (Kurniawan, Musa and Suharto, 2018)

According to Law No. 13 of 2003 concerning with the use of manpower, all things are interconnected between workers before, during or after their employment (Kemenprint, 2017).In 1970s, Central Bureau of Statistics established a working age limited on 10 years. However, since the National Labor Force Survey (SAKERNAS) was held, the results had changed the working age limited to above 15 years according to recommended regulation by International Labour Organization (Sutia, Adha and Fahlevi, 2019)

Some definitions of unemployment according to experts are as follows are Unemployment is defined as a situation in which a person belonging to the labour force is either not currently working or actively looking for job opportunities (Nanga, 2005); Unemployment is a factor which leads to a constrained economic growth. It also causes a reduced income stream for individuals which lead to poverty.

This promotes the government's effort to open up the opportunities, both in the public and private sector. Unemployment is also influenced by important factors such as number of employment opportunities, capital and education level (Sadono, 2006).

The Classical Theory explains that there are two reasons that cause unemployment that is (Inanc, 2018) Rigidity of Wage Level. The unions are not willing to accept this level of wages low wages when they are willing to accept a lower wage rate, then the demand for labor will increase, so that unemployment can lowered; The second stiffness arises from the part of the big business, which increases in strength monopoly, so that they can more freely determine the level of market prices 
Darwis Harahap, Ferri Alfadri, Yenni Samri Juliati Nasution, Nasir Ahmad Khan The Effect of Online Transportation System on Unemployment Rate and Public Welfare in Indonesia

Coordinating Ministry for People's Welfare defines welfare as a condition in which basic needs are met. these include food, clothing, health, education, housing, employment, a safe and comfortable environment. It is also defined as the fulfillment of the needs for the realization of moral society to Allah Subhanawata'ala (www.menkokesra.go.id, 2017).

According to Central Statistics Agency (BPS), interpreting the benchmarks of changes in the level or standard of social welfare has been studied in several fields. They include population, income, education, employment, consumption patterns, health. Housing environment and other social standards which are used as benchmarks in an effort to promote a better life quality (www.bps.go.id, 2017).

The concept of welfare in society can mean that welfare has a relative understanding. The concept of well-being cannot be separated of the quality of people's life, where the quality community life can be influenced by the socio-political and economic conditions of the community the. It was concluded that the definition of size Initially welfare was only measured through the physical and income aspects, but the development of today's welfare is measured through several indicators such as health, education and socioeconomic (Altuzarra, Gálvez-Gálvez, 2019) .

\section{Methodology}

This study used primary data in the form of questionnaires and interviews as initial observations. Furthermore Component Based Structure Equation Model (SEM) data analysis technique assisted by Smart PLS 3 program tool was used.

\section{Result and Discussion}

Respondent Characteristics

Table 1. Driver Age

\begin{tabular}{ccc}
\hline & Age & Total \\
\hline 1 & $18-25$ Years & 30 \\
2 & $26-36$ Years & 60 \\
3 & $>36$ Years & 10 \\
\hline & TOTAL & 100 \\
\hline
\end{tabular}


Table 2. Driver Education Level

\begin{tabular}{ccc}
\hline No & Education & Total \\
\hline 1 & Junior High School/equivalent & 2 \\
2 & Senior High School/equivalent & 72 \\
3 & Diploma-III/Bachelor/equivalent & 25 \\
4 & $>$ Bachelor & 1 \\
\hline & TOTAL & 100 \\
\hline
\end{tabular}

Table 3. GO-JEK Driver Income

\begin{tabular}{ccc}
\hline No & Income /Month & Total \\
\hline 1 & IDR 500.000 - IDR 1.000.000 & 3 \\
2 & IDR 1.000.000, - IDR 2.000.000 & 12 \\
3 & IDR 2.000.000 - IDR 3.000.000 & 60 \\
4 & IDR 3.000.000 - IDR 5.000.000 & 25 \\
\hline & TOTAL & 100 \\
\hline
\end{tabular}

\section{Structural Analysis of Equation Modeling with Smart PLS}

\section{Data Quality Test}

The reliability of forming construct was measured using the composite reliability items. In accordance with the opinion expressed by Imam Ghozali, the forming construct is declared to be reliable when the composite reliability is $>0.60$ (Ghozali, 2006).

Based on the results of statistical tests, it showed that each construct variable was considered reliable or fit. This implies that each question indicator size used as a construct was declared good, i.e. $>$ 0.9. The processed reliability test results are seen in table 5 below.

Table 4. Composite reliability

\begin{tabular}{cc}
\hline Forming Construct & Composite reliability \\
\hline Online Based Transportation & 0.922 \\
Unemployment Rate & 0.854 \\
Welfare & 0.945 \\
\hline
\end{tabular}

The individual reflective measure was high when the correlation value was $>0.50$ in the measured construct. Contruct with loading factor more effet 0,5 were used as the benchmark of this study, while those less effect were declared not good (Tentama, 2018). Measurement of discriminant validity was reviewed through the results of data processing with cross loading items on forming construct. When the correlation between the forming construct indicators produced highervalues compared to others, a good discriminant validity was formed. 
Darwis Harahap, Ferri Alfadri, Yenni Samri Juliati Nasution, Nasir Ahmad Khan

The Effect of Online Transportation System on Unemployment Rate and Public Welfare in Indonesia

Table 5. Cross loading indicators between constructs

\begin{tabular}{lcccc}
\hline $\mathbf{N O}$ & Indicators & $\begin{array}{c}\text { Online } \\
\text { Transportation }\end{array}$ & $\begin{array}{c}\text { Unemployment } \\
\text { Rate }\end{array}$ & $\begin{array}{c}\text { Public } \\
\text { welfare }\end{array}$ \\
\hline $\mathbf{1}$ & PL1 & 0.657 & 0.928 & 0.932 \\
$\mathbf{2}$ & PL2 & 0.962 & 0.824 & 0.795 \\
$\mathbf{3}$ & FX1 & 0.656 & 0.854 & 0.815 \\
$\mathbf{4}$ & FX2 & 0.756 & 0.715 & 0.717 \\
$\mathbf{5}$ & HB1 & 0.824 & 0.810 & 0.877 \\
$\mathbf{6}$ & HB2 & 0.855 & 0.735 & 0.623 \\
$\mathbf{7}$ & PT1 & 0.900 & 0.622 & 0.615 \\
$\mathbf{8}$ & PT2 & 0.828 & 0.822 & 0.857 \\
$\mathbf{9}$ & SB1 & 0.750 & 0.681 & 0.624 \\
$\mathbf{1 0}$ & SB2 & 0.680 & 0.572 & 0.425 \\
$\mathbf{1 1}$ & PB1 & 0.675 & 0.485 & 0.435 \\
$\mathbf{1 2}$ & PB2 & 0.786 & 0.910 & 0.820 \\
$\mathbf{1 3}$ & LP1 & 0.746 & 0.871 & 0.734 \\
$\mathbf{1 4}$ & LP2 & 0.667 & 0.752 & 0.726 \\
$\mathbf{1 5}$ & MO1 & 0.934 & 0.824 & 0.825 \\
$\mathbf{1 6}$ & MO2 & 0.648 & 0.755 & 0.785 \\
$\mathbf{1 7}$ & TP1 & 0.596 & 0.600 & 0.577 \\
$\mathbf{1 8}$ & TP2 & 0.920 & 0.982 & 0.902 \\
$\mathbf{1 9}$ & PDT1 & 0.545 & 0.505 & 0.987 \\
$\mathbf{2 0}$ & PDT2 & 0.639 & 0.624 & 0.875 \\
$\mathbf{2 1}$ & KO1 & 0.825 & 0.752 & 0.810 \\
$\mathbf{2 2}$ & KO2 & 0.578 & 0.626 & 0.812 \\
$\mathbf{2 3}$ & KES1 & 0.715 & 0.722 & 0.755 \\
$\mathbf{2 4}$ & KES2 & 0.710 & 0.688 & 0.625 \\
$\mathbf{2 5}$ & LK1 & 0.898 & 0.882 & 0.887 \\
$\mathbf{2 6}$ & LK2 & 0.685 & 0.714 & 0.987 \\
$\mathbf{2 7}$ & KS1 & 0.835 & 0.818 & 0.754 \\
$\mathbf{2 8}$ & KS2 & 0.720 & 0.750 & 0.828 \\
\hline & & & & \\
\hline
\end{tabular}

Based on the standard values used to assess the validity level, the data in this study were categorized as valid because the data findings were $>0.5$ (Ghozali, 2006).

Structually, it was evaluated using the results of R-square test on the dependent variable ( $\mathrm{Z}$ and $\mathrm{Y}$ ) and t-statistical data test including the significance of structural path coefficient value. The R-Square test results with Smart PLS are seen in table 6 .

Table 6. R-Square

\begin{tabular}{cc}
\hline Variables & R-Square \\
\hline Unemployment & 0.824 \\
Welfare & 0.910 \\
\hline
\end{tabular}




\section{Research Model}

The results of data testing were assisted by the Smart PLS3 software tool.The path diagram used in this study is as follows.

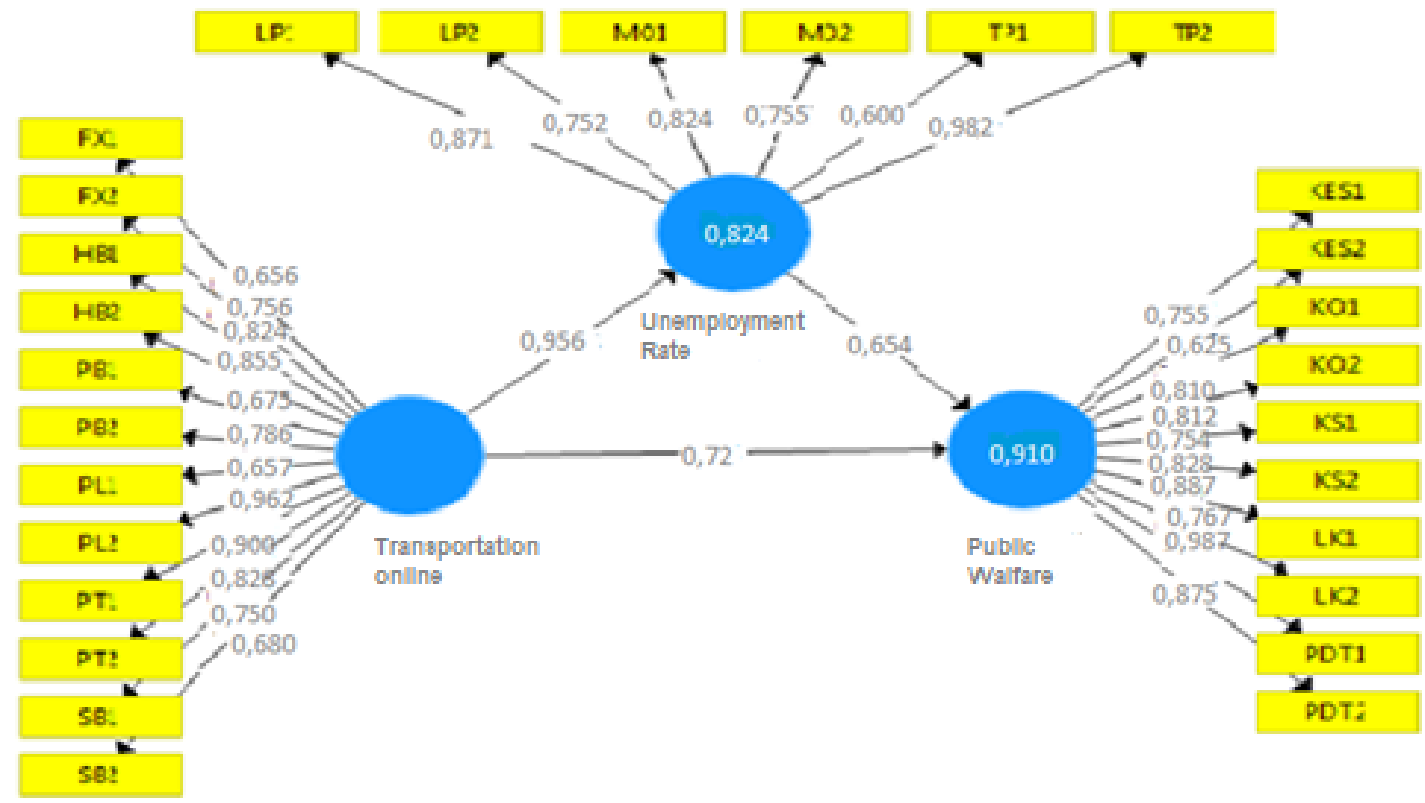

Figure 2. Structural Model of Research Equation Modeling

The model formed is seen from the loading factor created by each indicator. It is also listed in table 8 below.

Table 7. Outer Loading Model

\begin{tabular}{|c|c|c|c|c|}
\hline No & Indicators & $\begin{array}{l}\text { Online-based } \\
\text { Transportation }\end{array}$ & $\begin{array}{c}\text { Unemployment } \\
\text { Rate }\end{array}$ & Welfare \\
\hline 1 & PL 1 & 0.657 & & \\
\hline 2 & PL 2 & 0.962 & & \\
\hline 3 & FX 1 & 0.656 & & \\
\hline 4 & FX 2 & 0.756 & & \\
\hline 5 & HB 1 & 0.824 & & \\
\hline 6 & HB 2 & 0.855 & & \\
\hline 7 & PT 1 & 0.900 & & \\
\hline 8 & PT 2 & 0.828 & & \\
\hline 9 & SB 1 & 0.750 & & \\
\hline 10 & SB 2 & 0.680 & & \\
\hline 11 & PB 1 & 0.675 & & \\
\hline 12 & PB 2 & 0.786 & & \\
\hline 13 & LP 1 & & 0.871 & \\
\hline 14 & LP 2 & & 0.752 & \\
\hline
\end{tabular}


Darwis Harahap, Ferri Alfadri, Yenni Samri Juliati Nasution, Nasir Ahmad Khan

The Effect of Online Transportation System on Unemployment Rate and Public Welfare in Indonesia

\begin{tabular}{lccc}
$\mathbf{1 5}$ & MO 1 & 0.824 & \\
$\mathbf{1 6}$ & MO 2 & 0.755 & \\
$\mathbf{1 7}$ & TP 1 & 0.600 & \\
$\mathbf{1 8}$ & TP 2 & 0.982 & \\
$\mathbf{1 9}$ & PDT 1 & & 0.987 \\
$\mathbf{2 0}$ & PDT 2 & 0.875 \\
$\mathbf{2 1}$ & KO 1 & 0.810 \\
$\mathbf{2 2}$ & KO 2 & 0.812 \\
$\mathbf{2 3}$ & KES 1 & 0.755 \\
$\mathbf{2 4}$ & KES 2 & 0.625 \\
$\mathbf{2 5}$ & LK 1 & 0.887 \\
$\mathbf{2 6}$ & LK 2 & 0.987 \\
$\mathbf{2 7}$ & KS 1 & 0.754 \\
$\mathbf{2 8}$ & KS 2 & & 0.828 \\
\hline
\end{tabular}

The loading terms used were greater \pm 0.30 , loading greater \pm 0.40 is declared urgent and loading greater \pm 0.50 is significant. From the table above, it was explained that the modeling of the indicators tested was declared fit because all loading factors were greater 0.50. urthermore, the model used on this study was seen through the results of the validity and reliability on the forming construct indicators (Ghozali, 2006).

\section{Construct Validity Testing}

Constuct validity test at determining the T-statistic value for each construct indicator. Indicators with T-statistic value greater 1.96 are declared valid. Theyare also declared when the P-value is greater 0.05. From the Bootstraping calculation of the modeling test, Outer Loading was obtained(Ghozali, 2006).

Table 8. Outer Loading

\begin{tabular}{lccccc}
\hline \multicolumn{1}{c}{ Indicators } & $\begin{array}{c}\text { Original } \\
\text { Sample } \\
\mathbf{( O )}\end{array}$ & $\begin{array}{c}\text { Sample } \\
\text { Mean } \\
(\mathbf{M})\end{array}$ & $\begin{array}{c}\text { Standard } \\
\text { Deviation } \\
\text { (STDEV) }\end{array}$ & $\begin{array}{c}\text { T } \\
\text { Statistics } \\
(/ \mathbf{O} / \text { STD } \\
\text { EV/) }\end{array}$ & $\begin{array}{c}\text { P } \\
\text { Values }\end{array}$ \\
\hline $\begin{array}{l}\text { PL1<-Online Based } \\
\text { Transportation } \\
\text { PL2<-Online Based }\end{array}$ & 0.657 & 0.739 & 0.058 & 12.810 & 0.000 \\
$\begin{array}{l}\text { Transportation } \\
\text { FX1<-Online Based } \\
\text { Transportation }\end{array}$ & 0.962 & 0.841 & 0.030 & 28.122 & 0.000 \\
$\begin{array}{l}\text { FX2<-Online Based } \\
\text { Transportation }\end{array}$ & 0.756 & 0.907 & 0.026 & 35.114 & 0.000 \\
$\begin{array}{l}\text { HB1<-Online Based } \\
\text { Transportation }\end{array}$ & 0.824 & 0.870 & 0.071 & 10.197 & 0.000 \\
\hline & & & & 24.452 & 0.000 \\
\hline
\end{tabular}




\begin{tabular}{|c|c|c|c|c|c|}
\hline $\begin{array}{l}\text { HB2<-Online Based } \\
\text { Transportation }\end{array}$ & 0.855 & 0.697 & 0.056 & 12.571 & 0.000 \\
\hline $\begin{array}{l}\text { PT1<-Online Based } \\
\text { Transportation }\end{array}$ & 0.900 & 0.707 & 0.065 & 10.954 & 0.000 \\
\hline $\begin{array}{l}\text { PT2<-Online Based } \\
\text { Transportation }\end{array}$ & 0.828 & 0.858 & 0.029 & 30.011 & 0.000 \\
\hline $\begin{array}{l}\text { SB1<-Online Based } \\
\text { Transportation }\end{array}$ & 0.750 & 0.623 & 0.085 & 7.420 & 0.000 \\
\hline $\begin{array}{l}\text { SB2<- Online Based } \\
\text { Transportation }\end{array}$ & 0.680 & 0.560 & 0.065 & 8.508 & 0.000 \\
\hline $\begin{array}{l}\text { PB1<- Online Based } \\
\text { Transportation }\end{array}$ & 0.675 & 0.529 & 0.081 & 6.526 & 0.000 \\
\hline $\begin{array}{l}\text { PB2<- Online Based } \\
\text { Transportation }\end{array}$ & 0.786 & 0.954 & 0.007 & 132.101 & 0.000 \\
\hline $\begin{array}{l}\text { LP1<- Unemployment } \\
\text { Rate }\end{array}$ & 0.871 & 0.871 & 0.046 & 18.709 & 0.000 \\
\hline $\begin{array}{l}\text { LP2<- Unemployment } \\
\text { Rate }\end{array}$ & 0.752 & 0.752 & 0.055 & 13.182 & 0.000 \\
\hline $\begin{array}{l}\text { MO1<-Unemployment } \\
\text { Rate }\end{array}$ & 0.824 & 0.824 & 0.008 & 25.359 & 0.000 \\
\hline $\begin{array}{l}\text { MO2<-Unemployment } \\
\text { Rate }\end{array}$ & 0.755 & 0.755 & 0.055 & 13.959 & 0.000 \\
\hline $\begin{array}{l}\text { TP1<-Unemployment } \\
\text { Rate }\end{array}$ & 0.600 & 0.600 & 0.080 & 7.580 & 0.000 \\
\hline $\begin{array}{l}\text { TP2<-Unemployment } \\
\text { Rate }\end{array}$ & 0.982 & 0.982 & 0.006 & 149.416 & 0.000 \\
\hline PDT1<Welfare & 0.987 & 0.615 & 0.987 & 7.326 & 0.000 \\
\hline PDT2<Welfare & 0.875 & 0.711 & 0.875 & 12.455 & 0.000 \\
\hline KO1<Welfare & 0.810 & 0.807 & 0.810 & 18.072 & 0.000 \\
\hline KO2<Welfare & 0.812 & 0.708 & 0.812 & 8.765 & 0.000 \\
\hline KES1<Welfare & 0.755 & 0.763 & 0.755 & 13.245 & 0.000 \\
\hline KES2<Welfare & 0.625 & 0.755 & 0.625 & 12.825 & 0.000 \\
\hline LK1<Welfare & 0.887 & 0.856 & 0.887 & 24.998 & 0.000 \\
\hline LK2 $<$ Welfare & 0.987 & 0.780 & 0.987 & 10.245 & 0.000 \\
\hline KS1<Welfare & 0.754 & 0.835 & 0.754 & 10.780 & 0.000 \\
\hline KS2<Welfare & 0.828 & 0.757 & 0.828 & 23.419 & 0.000 \\
\hline
\end{tabular}

Based on the results of the data test in table 10, it was stated that each forming construct indicator had a T-statistic result greater 1.96 and P-Value lower 0.05. Therefore, all the 
Darwis Harahap, Ferri Alfadri, Yenni Samri Juliati Nasution, Nasir Ahmad Khan

The Effect of Online Transportation System on Unemployment Rate and Public Welfare in Indonesia

forming onstructs were declared valid and used as a measure for hypothesis testing at the stage of structural measurement.

\section{Structural Model Evaluation}

Evaluation on analysis model is needed to assess the significance level of the correlation between constructs assessed through T-statistics obtained from the output of processed data testing by calculating PLS Bootstraping. The influence rate between constructs and interactions which occured was measured by the amount of path coefficient value created. The path coefficient created by T-statistic value $\geq 1.96$ and $\mathrm{P}$-value $\leq 0.05$ was stated to have a significant effect (Ghozali, 2006).

With the help of Smart PLS software, path diagram with T-statistic value was created. Table of path coefficients is shown in Figure 4 below:

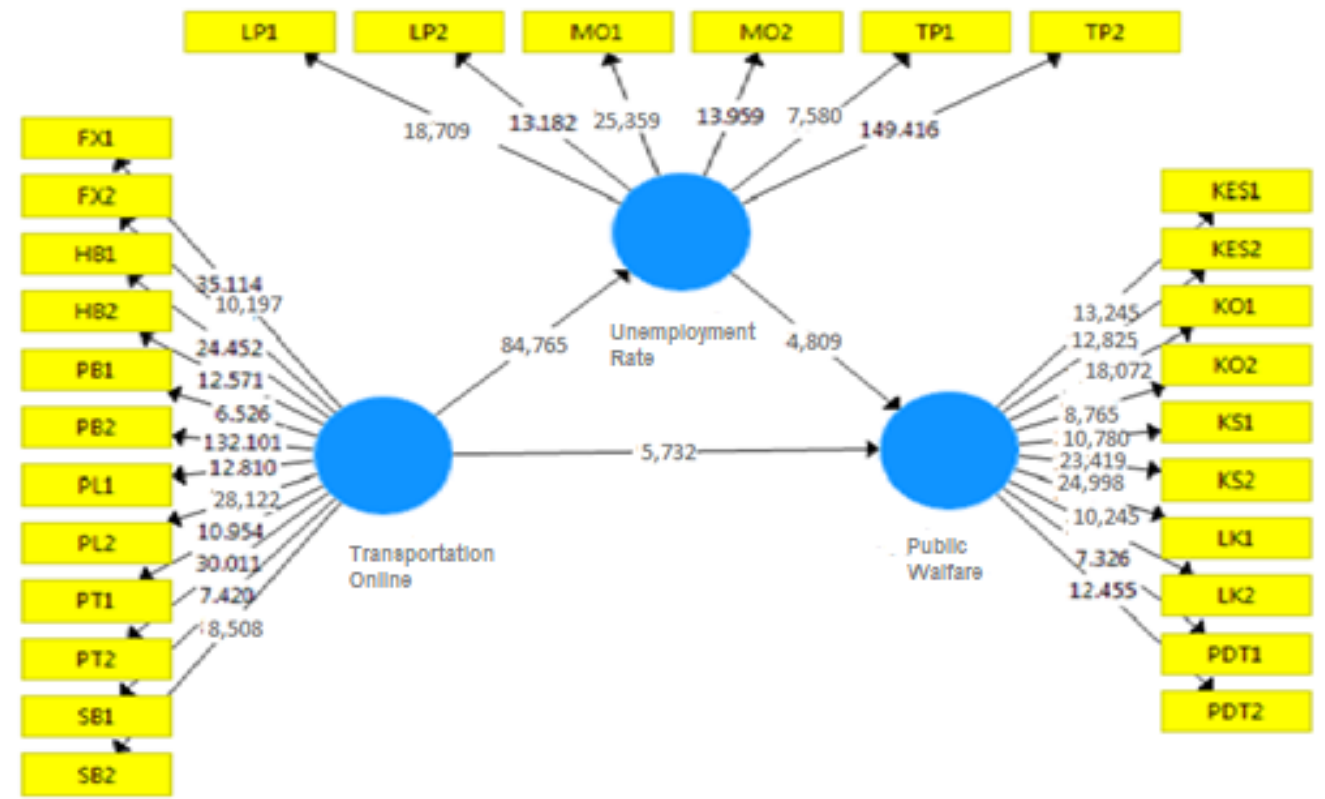

Figure 4 . T-statistic and Path Diagram

Table 9. T-test and P-Value

\begin{tabular}{|c|c|c|c|c|c|}
\hline & $\begin{array}{c}\text { Origi } \\
\text { nal } \\
\text { Samp } \\
\text { le } \\
(\mathrm{O})\end{array}$ & $\begin{array}{c}\text { Mean } \\
(\mathbf{M})\end{array}$ & $\begin{array}{l}\text { Standard } \\
\text { Deviation } \\
\text { (STDEV) }\end{array}$ & $\begin{array}{c}\text { T-Statistic } \\
\text { (/O/STDE } \\
\text { V/) }\end{array}$ & P-Values \\
\hline $\begin{array}{c}\text { OnlineTransportation -> } \\
\text { Welfare }\end{array}$ & 0.524 & 0.528 & 0.082 & 5.732 & 0.000 \\
\hline $\begin{array}{c}\text { Online Transportation -> } \\
\text { Unemployment }\end{array}$ & 0.976 & 0.948 & 0.021 & 84.765 & 0.000 \\
\hline $\begin{array}{c}\text { Unemployment-> } \\
\text { Welfare }\end{array}$ & 0.453 & 0440 & 0.083 & 4.809 & 0.000 \\
\hline
\end{tabular}


Based on the data test results, the hypothesis testing was carried out by comparing T-Value with a significance value of 0.05 . When $T-V$ alue was $\geq 1.96$ or $\mathrm{P}-$ Value was $\leq 0.05, \mathrm{H} 0$ was rejected and $\mathrm{H} 1$ accepted.

\section{Discussion}

The presence of means of transportation based online applications, such as GO-JEK at Indonesia makes people feel that the need for mobility other than using the means of transportation traditional, very important. Presence GO-JEK in Medan is attracting attention society to find out more regarding this online transportation. Since his presence, starting from doing marketing and dissemination on a large scale, whether through television media, media mass and print media make it easy the public knows information about online application based transportation.

\section{Online Transportation System in reducing the unemployment rate.}

Based on the statistical data test results, it was stated that the forming constructs of the online transportation system had a significant positive effect on the reduction of unemployment. This was proven from the t-statistical test value which was $>1.96$, i.e equaled o 84.765 and H1 was accepted.

Therefore, it was stated that the presence of job opportunities as drivers in the online transportation system was an alternative solution to minimize unemployment growth.

\section{Influence of online transportation systems onpublic welfare}

Based on the results of statistical data test processing, it was stated that theforming constructs of the online transportation system hada significant positive effect on the public elfare. This was proven from the measurement of t-statistic value which was $>1.96$, i.e 5.732 and H1 was accepted. Therefore, it was stated that the emergence of job opportunities as drivers in the online transportation system was able to improve the lives of GO-JEK drivers and their families.

\section{The effect of online transportation on public welfare through reducing the unemployment rate}

Based on the results of the statistical processing, it was stated that the forming constructs of the online transportation system had a significant positive effect on public welfare. This was proven by the t-statistic value which was $>1.96$, i.e 4.809 . 


\section{Darwis Harahap, Ferri Alfadri, Yenni Samri Juliati Nasution, Nasir Ahmad Khan}

The Effect of Online Transportation System on Unemployment Rate and Public Welfare in Indonesia

Furthermore, Itwas concluded that H1 is accepted as a whole. Therefore, this proves that the presence of job opportunities as drivers in Online transportation systems was able to reduce the unemployment rate and also improve people's lives (GO-JEK drivers, their environment and families).

\section{Conclusion}

Based on the statistical data test results, it was stated that the forming constructs of the online transportation system had a significant positive effect on the reduction of unemployment. In addition, the online transportation system had a significant positive effect on the public welfare. To conclude, the presence of job opportunities as drivers in online transportation systems was able to reduce the unemployment rate and also improve people's lives (GO-JEK drivers, their environment and families).

\section{References}

Altuzarra, A., Gálvez-Gálvez, C. and González-Flores, A. (2019) 'Economic Development and Female Labour Force Participation: The Case of European Union Countries', Sustainability, 11(7), p. 1962. doi: 10.3390/su11071962.

Badan Pusat Statistik (2018). Available at: https://www.bps.go.id/ (Accessed: 19 May 2021).

Beranda | Kementerian Koordinator Bidang Pembangunan Manusia dan Kebudayaan (2018). Available at: https://www.kemenkopmk.go.id/ (Accessed: 19 May 2021).

Farrugia, D. (2019) 'The formation of young workers: The cultivation of the self as a subject of value to the contemporary labour force', Current Sociology, 67(1), pp. 47-63. doi: $10.1177 / 0011392118793681$.

Franita, R. (2016) 'Analisa Pengangguran Di Indonesia', 1, p. 6.

Gao, Y. and Chen, J. (2019) 'The Risk Reduction and Sustainable Development of Shared Transportation: The Chinese Online Car-hailing Policy Evaluation in the Digitalization Era', Sustainability, 11(9), p. 2596. doi: 10.3390/su11092596.

Ghozali, Imam, Struktural Equation Modeling Metode Alternatif dengan Partial Least Square, (Badan

Penerbit Universitas Diponegoro, 2006),

Inanc, H. (2018) 'Unemployment, Temporary Work, and Subjective Well-Being: The Gendered Effect of Spousal Labor Market Insecurity', American Sociological Review, 83(3), pp. 536-566. doi: 10.1177/0003122418772061.

Kementerian Perindustrian (2018). Available at: https://kemenperin.go.id/ (Accessed: 19 May 2021). 
Kurniawan, A., Musa, A. H. and Suharto, R. B. (2018) 'Faktor-Faktor yang Mempengaruhi Tingkat Pengangguran di Provinsi Kalimantan Timur', FORUM EKONOMI, 19(2), p. 131. doi: 10.29264/jfor.v19i2.2119.

Martati, I., . S. and Syarifuddin, A. (2013) 'Model Penciptaan Lapangan Kerja Melalui Pengembangan Ekonomi Lokal Pada Kecamatan Samarinda Ilir', Jurnal Manajemen dan Kewirausahaan, 15(2), pp. 123-130. doi: 10.9744/jmk.15.2.123-130.

Muana, Nanga, Makro Ekonomi Teori Masalab dan Kebijakan, (Jakarta, PT.Raja Grafindo Persada, 2005)

Okezone | Berita Terbaru | Berita Hari Ini | Berita Online (no date). Available at: https://www.okezone.com/ (Accessed: 19 May 2021).

Özge KILIÇ, N. (2018) 'İşsizlik Histerisi Hipotezi Fransa, Almanya Ve Türkiye İçin Geçerli Mi? Yapisal', Journal of Turkish Studies, 13(Volume 13 Issue 30), pp. 213-223. doi: 10.7827/TurkishStudies.14251.

Razak MASHUR et al. (2019) 'Moving From Traditional to Society 5.0: Case study by Online Transportation Business', 유통과학연구, 17(9), pp. 93-102. doi: 10.15722/JDS.17.9.201909.93.

Sutia, S., Adha, S. and Fahlevi, M. (2019) 'Why do Customers Intend to Repurchase Transportation Online in Indonesia?', E3S Web of Conferences. Edited by Hadiyanto, Budi Warsito, and Maryono, 125, p. 23010. doi: 10.1051/e3sconf/201912523010.

Sukirno, Sadono, Makro Ekonomi Teori Pengantar, (Jakarta: PT. Raja Grafindo Persada, 2006)

Tansel, A. and Ozdemir, Z. A. (2018) 'Unemployment invariance hypothesis, added and discouraged worker effects in Canada', International Journal of Manpower, 39(7), pp. 929-936. doi: 10.1108/IJM-04-2017-0059.

Tentama, F. and . S. (2018) 'Pengujian Validitas dan Reliabilitas Konstruk pada Organizational Citizenship Behavior', HUMANITAS, 15(1), p. 62. doi: 10.26555/humanitas.v15i1.5282. 